ISSN: 2224-0616

Int. J . Agril. Res. Innov. Tech. 8 (2): 24-31, December 2018

DOI: https:// doi.org/ 10.3329/ijarit.v8i2.40552

Available online at https://ijarit.webs.com

https:// www.banglajol.info/index.php/ IJ ARIT

\title{
EFFECTS OF DIFFERENT AMOUNTS OF ORGANIC FERTILIZERS ON GROWTH AND PRODUCTION OF TILAPIA IN MONOCULTURE
}

\author{
P. Chowdhury'*, M.Z. Hossain ${ }^{2}$, N.A. Raushon ${ }^{3}$ and M.S. Rahman ${ }^{4}$ \\ Received 30 July 2018, Revised 26 November 2018, Accepted 26 December 2018, Published online 31 December 2018
}

\begin{abstract}
The experiment was conducted to determine the effects of different amounts of organic fertilizers on growth and production of Tilapia (monosex GIFT tilapia) in monoculture system for a period of 120 days. The experiment was carried out in six earthen ponds, which were situated at the south-east corner of the Fisheries Faculty Building under the Department of Fisheries Management, Bangladesh Agricultural University, Mymensingh. The experiment was designed with three treatments and each of them consisted of two replications. Fish population density was 120 fish per decimal for all the treatments. Ponds were treated with organic fertilizers (cow dung) at the rate of $2 \mathrm{~kg}, 4 \mathrm{~kg}$ and $6 \mathrm{~kg}$ per decimal were supplied fortnightly for treatment-I, treatment-II and treatment-III, respectively. The ranges of water temperature, transparency, dissolved oxygen, total alkalinity, free $\mathrm{CO} 2$, phosphate-phosphorus and nitrate-nitrogen found were 15.82 to $24.49{ }^{\circ} \mathrm{C}, 17.00$ to 32.00 $\mathrm{cm}, 7.00$ to $10.30 \mathrm{mg} \mathrm{L}^{-1}$, $\mathrm{pH} 7.20$ to $7.90,140.00$ to $192.00 \mathrm{mg} \mathrm{L}^{-1}, 2.00$ to $6.00 \mathrm{mg} \mathrm{L}^{-1}, 1.40$ to $1.95 \mathrm{mg} \mathrm{L}^{-1}$ and 3.30 to $3.73 \mathrm{mg} \mathrm{L}^{-1}$, respectively. All the physical and chemical parameters except temperature were within the productive range and more or less similar among all the ponds under three treatments. 18 genera of phytoplankton under five major groups and 9 genera of zooplankton under three major groups were identified in the experimental ponds. Average survival rate of fish under treatment-I, treatment-II, and treatment-III were $94.50 \%, 94.00 \%$ and $95.00 \%$, respectively. The calculated net fish production under treatment-I was 3.554 ton ha-1 $\mathrm{yr}^{-1}$ and that under treatment-II was 3.648 ton ha-1 $\mathrm{yr}^{-1}$ and under treatment-III was 2.919 ton ha-1 $\mathrm{yr}^{-1}$. The net fish productions under treatment-II and treatment-III were $102.64 \%$ and $82.13 \%$ comparing with treatment on which was taken for $100 \%$. According to cost-benefit analysis, the ratios of net profit under treatments I, II, and III were 1:0.81, 1:0.54, and 1:0.04. According to specific growth rate, treatment-II was the best and survival rate of treatment-III was the best, and according to cost-benefit analysis, treatment-I (ratio 1:0.81) was the best. So, organic fertilizer at the rate of $2 \mathrm{~kg}$ per decimal (treatment-I) was considered the best among three treatments in this experiment.
\end{abstract}

Keywords: Tilapia, Fertilizer, Production, Water Quality

${ }^{1}$ Scientific officer, Bangladesh Fisheries Research Institute, Headquarters, Mymensingh-2201, Bangladesh

${ }^{2}$ Department of Fisheries Management, Bangladesh Agricultural University, Mymensingh-2202, Bangladesh

${ }^{3}$ Scientific officer, Bangladesh Fisheries Research Institute, Freshwater Station, Mymensingh-2201, Bangladesh

${ }^{4}$ Professor, Department of Fisheries Management, Bangladesh Agricultural University, Mymensingh-2202, Bangladesh

*Corresponding author's email: nitoldhk@gmail.com (P. Chowdhury)

Cite this article as: Chowdhury, P., Hossain, M.Z., Raushon, N.A. and Rahman, M.S. (2018). Effects of different amounts of organic fertilizers on growth and production of tilapia in monoculture. Int. J. Agril. Res. Innov. Tech. 18(2), 24-31.

\section{Introduction}

Bangladesh is situated in the tropical region of the world and the climatic condition of Bangladesh is very much suitable for fisheries. Fisheries sector plays a significant role in socioeconomic development, employment generation, poverty alleviation, nutrition supply and earning of foreign exchange. Fish contribute a large amount of animal protein to the diets of people in Bangladesh, about $63 \%$ of which comes from aquatic animals (DoF, 2011). Inland waters may be classified as inland open water and inland closed water resources. Inland waters include haors, baors, beels, rivers, canals and ponds. Bangladesh also has extensive marine water resources. However, at present the situation has changed due to environmental degradation, pollution, extensive fishing pressure on natural water bodies and use of banned fishing gear. For this reason to meet up the growing demand of aquaculture has the greatest potential in Bangladesh. 
Tilapia is an integral component of subsistence fisheries for thousands of years but has gained popularity in recent years. Tilapia is a better performing species in the pond aquaculture system of Bangladesh. Tilapia culture in Bangladesh has become popular because of its high tolerance to adverse environmental conditions, relatively fast growth rate and availability of fry. Tilapia can tolerate dissolved oxygen concentration of $1 \mathrm{mg} \mathrm{L}^{-1}$ and can survive using atmospheric oxygen when DO concentration dropped to less than $1 \mathrm{mg} \mathrm{L}^{-1}$. Tilapia is the common name, which is used to describe three genera of fish in the family Cichlidae: Oreochromis, Sarotherodon, and Tilapia, which are ubiquitous inmany countries of the world. Tilapia culture in tropical and subtropical countries is practiced at either extensive or semi intensive levels. The semiintensive culture of tilapia is particularly ideal in developing countries because it provides a wide variety of options in management and capital investments. Management strategies in the lower levels of intensification involve the use of fertilizer to enhance natural productivity and to improve the levels of dissolved oxygen. Fish yields from such techniques have been found to be higher than those from unfertilized systems. Therefore, to increase production of fish in pond fertilization is a prime need. Organic fertilizers have a long tradition in tropical semi-intensive aquaculture. The manuring of fish pond is considered an important scientific discipline for increasing fish production. When added to ponds, they may ultimately increase fish yields through soluble or particulate pathways. Release of soluble nitrogen $(\mathrm{N})$ and phosphorous (P) stimulates algal production, which in turn can be consumed by fish directly or after intermediate processing by zooplankton or microbes (detritus formation). In waters with low alkalinities, manure decomposition may also provide algae with an important source of dissolved inorganic carbon (DIC) through decomposition and release of carbon dioxide. One of the common approaches for increasing fish production in ponds is the direct application of fertilizer, which enhances the production of phytoplankton, a natural food item for fishes. Pond fertilization practices using animal wastes are widely used in many countries to sustain productivity at low cost (Gupta and Noble, 2001). A year old traditional aquaculture practice, administration of cow dung on fresh water fish culture ponds has brought out several admirable results from the past till today. Fertilizing the ponds with cow dung is so far the most useful technique to provide basic nutrients to enhance the natural productivity through production either of aquatic biota, which serve directly or indirectly as the food of fishes. Production of cultivated fish can be increased by introducing organic and inorganic fertilizers of different origin in fish ponds to increase the primary productivity. Live feeds increase the survival rate and quality of larvae and fingerlings. So using low cost manures is the most effective way to increase live feed production in ponds and thereby raising fry and fingerlings. The organic fertilizers mainly increase the quantity of primary producers. Animal manures have a long history of use as a source of soluble phosphorus, nitrogen and carbon for algal growth and natural food production (Knud-Hansen, 1998) hence resulting higher fish yield. Cow manure treatment in major carps nursery ponds yield 50-60 percent more fish than untreated ponds (Saha et al., 1980). Cattle manure applied to fish pond at the daily rate of $3-4 \%$ of fish, fish yielded $20-30 \mathrm{~kg}^{1} \mathrm{ha}^{-1}$ day $^{-1}$. Manure also improve the quality of bottom soil of pond in respect of organic carbon, colloidal structure etc. Large quantity of organic fertilizers reduces seepage from sandy bottom pond. New pond needed higher amount of manure and old pond need less amount. In contrast to many advantages, organic fertilizers when applied in a high dose create several problems, such as a) reduction of dissolve oxygen for high bacterial decomposition of manure added, b) increase free CO2 due to high organic decomposition, c) increase the concentration of ammonia, d) may reduce sunlight penetration into water through producing phytoplankton bloom, and e) organic fertilizers may introduce pathogens or parasites with them which may cause fish disease. (Rahman, 1992). For this reason, the aim of this experiment is to find out the proper and suitable dose of cow dung to be added in the pond, which won't cause water quality degradation and provide proper plankton growth and thus increase the production of fish.

\section{Materials and Methods}

\section{Experimental duration and location}

The duration of the experiment was 4 months from November 2014 to February 2015 in six ponds. The ponds were situated at the southeast corner of the Faculty of Fisheries Buildings, Bangladesh Agricultural University, Mymensingh.

\section{Experimental ponds}

Six earthen ponds were used for the experiment. The area of each pond was of about $40 \mathrm{~m}^{2}$ (1 decimal). All the experimental ponds were arbitrarily numbered as pond no. 1(P1), pond no. 2 (P2), pond no. 3 (P3), pond no. 4 (P4), pond no. 5 (P5) and pond no. 6 (P6) for the convenience of the research work. Ponds 1 and 4 were under treatment no. I, ponds 2 and 3 were under treatment no. II and ponds 5 and 6 were under treatment no. III. 


\section{Experimental Design}

The experimental layout has been given in the Table 1 below:

Table 1. The layout of the experiment.

\begin{tabular}{|c|c|c|c|c|c|}
\hline Treatments & Replications & Pond no. & Fish species & $\begin{array}{l}\text { Fish Population } \\
\text { Density }\end{array}$ & Fertilization \\
\hline T-I & $\begin{array}{c}2 \\
\text { (2 ponds) }\end{array}$ & $\mathrm{P}_{1}, \mathrm{P}_{6}$ & $\begin{array}{c}\text { Tilapia } \\
\text { (Oreochromis } \\
\text { niloticus) }\end{array}$ & 120 fish per decimal & $\begin{array}{l}2 \text { kg per decimal per } \\
2 \text { weeks }\end{array}$ \\
\hline T-II & -Do- & $\mathrm{P}_{3}, \mathrm{P}_{4}$ & do & do & $\begin{array}{l}4 \mathrm{~kg} \text { per decimal per } \\
2 \text { weeks }\end{array}$ \\
\hline T-III & -Do- & $\mathrm{P}_{2,} \mathrm{P}_{5}$ & do & do & $\begin{array}{l}6 \mathrm{~kg} \text { per decimal per } \\
2 \text { weeks }\end{array}$ \\
\hline
\end{tabular}

\section{Pond preparation}

Pond drying, dyke repairing and liming

Before starting the experiment, the ponds were dried, aquatic higher vegetations and unwanted aquatic animals were removed manually. Pond dykes were repaired and renovated. Liming $(\mathrm{CaO})$ was done in all the ponds at rate of $1 \mathrm{~kg} \mathrm{decimal}^{-1}$ before 7 days of fertilization.

Water supply

Ponds were supplied with water after 7 days of liming from a deep tube-well water supply system; rainfall was also a source of water supply to the ponds.

\section{Fertilization of the ponds}

Before 10 days of releasing of fish fry fertilization of all the ponds were done with partially decomposed cow dung. During the experiment, fertilization of ponds was done fortnightly. During fertilization, partially decomposed cowdung was formed into small balls and thrown into the pond.

\section{Stocking of fish}

Fingerlings of monosex GIFT tilapia (O. niloticus) were stocked in all the ponds. The initial average weight of $\mathrm{O}$. niloticus was $9.46 \mathrm{~g}$ and initial average length of O. niloticus was $6.18 \mathrm{~cm}$.

\section{Study of water quality parameters}

Different types of water quality parameters were estimated and recorded fortnightly throughout the experimental period.

\section{Methods for study of physical parameters}

Water depth (m)

Depth of water of all the experimental ponds was measured with the help of a graduated wooden depth meter.

Transparency (cm)

Water transparency of the experimental ponds was measured by a Secchi-disk.
Temperature $\left({ }^{\circ} \mathrm{C}\right)$

Data of air and water temperature $\left({ }^{\circ} \mathrm{C}\right)$ were collected from 'weather yard' of the Department of Irrigation and Water Management of the Faculty of Agricultural Engineering and Technology, Bangladesh Agricultural University, Mymensingh.

\section{Methods for study of chemical parameters}

Dissolved oxygen $\left(\mathrm{mg} \mathrm{L}^{-1}\right)$

Dissolved oxygen of water was measured with the help of a portable digital dissolved oxygen (DO) meter (Milwaukee, SM600 Smart DO Meter).

$\mathrm{pH}$ (Hydrogen-ion concentration)

$\mathrm{pH}$ was determined by a portable digital $\mathrm{pH}$ meter (Hanna Instruments).

\section{Free carbon dioxide $\left(\mathrm{mg} \mathrm{L}^{-1}\right)$}

To determine free carbon dioxide of water, samples were collected in $250 \mathrm{ml}$ black plastic bottles and titrated with $0.0227 \mathrm{~N}$ sodium hydroxide solution using phenolphthalein as indicator.

\section{Total alkalinity ( $\left.\mathrm{mg} \mathrm{L}^{-1}\right)$}

For measuring total alkalinity, samples were collected in $250 \mathrm{ml}$ black plastic bottles and total alkalinity of water samples was determined by titrimetric method using methyl orange indicator.

\section{Phosphate-phosphorus (PO4-P)}

A digital Phosphate Meter was used to measure Phosphate-phosphorus (PO4-P) of water samples of the ponds (model HI 93717, Hanna Instruments).

\section{Nitrate-nitrogen (NO3-N)}

Nitrate-nitrogen (NO3-N) was measured with the help of a digital Nitrate Meter (model HI 93728, Hanna Instruments). 


\section{Methods for study of biological parameters}

Collection and preservation of plankton sample

Water samples were randomly collected in a 500 $\mathrm{ml}$ bottle for quantitative and qualitative analysis of phytoplankton and zooplankton of water from different locations of each of the ponds and passed through a plankton net (mesh-size $55 \mu$ ) and finally concentrated to $100 \mathrm{ml}$. Then concentrated samples were preserved in small plastic bottles in $5 \%$ formalin for further study under a compound microscope.

Counting of plankton

For counting both phytoplankton and zooplankton Sedgwick-Rafter Counting Cell (S-R cell) was used.

Calculation of plankton

The plankton population was determined by Sedgwick Rafter Counting Cell (S-R Cell) using the following formula (Rahman, 1992):

$\mathrm{N}=\frac{\mathrm{A} \times 1000 \times \mathrm{C}}{\mathrm{V} \times \mathrm{F} \times \mathrm{L}}$

Where,

$\mathrm{N}=$ No. of plankton cells per liter of original water

$\mathrm{A}=$ Total no. of plankton counted

$\mathrm{C}=$ Volume of final concentrate of the sample in $\mathrm{ml}$

$\mathrm{V}=$ Volume of a field $=1 \mathrm{~mm}^{3}$

$\mathrm{F}=$ No. of the fields counted

$\mathrm{L}=$ Volume of original water in liter

The number of phytoplankton and zooplankton were expressed as cells $\mathrm{L}^{-1}$

\section{Harvesting of fish}

At the end of the experiment the water of the ponds were pumped out and all the fish were harvested.

\section{Estimation of survival rate, growth and} production of fish

(i) The survival rate was estimated by the following formula

Survival rate $(\%)=\frac{\text { Noof harvested fishes }}{\text { Jritial no. of fishes }} \times 100$

(ii) Specific growth rate (SGR \%) was estimated by the following formula:

SGR $(\%$ per day $)=\frac{\log _{\varepsilon} W_{2}-\log _{8} W_{1}}{T_{2}-T_{1}} \times 100$

Where,

$\mathrm{W}_{1}=$ Initial live body weight $(\mathrm{g})$ at time $\mathrm{T}_{1}$

$\mathrm{W}_{2}=$ Final live body weight $(\mathrm{g})$ at time $\mathrm{T}_{2}$

(iii) Calculation of gross fish production (ton ha-1 $\left.\mathrm{yr}^{-1}\right)=$

Gross weight (kg) of fish pen decimal per month $\times 250 \times 12$ 1000

(iv) Calculation of net fish production (ton ha- ${ }^{-1} \mathrm{yr}^{-1}$ ) $=$

Net weight $(\mathrm{kg})$ cf fish per decimal per month $\times 250 \times 12$ 1000

\section{Statistical analysis}

T-test of net fish production of the ponds under three treatments was done by a computer using SPSS package programme.

\section{Results}

\section{Physico-chemical parameters}

The results of the different physico-chemical parameters of the experimental ponds have been presented in the Table 2 .

Table 2. Physico-chemical parameters (Mean $\pm \mathrm{SD}, \mathrm{n}=3$ ) of the ponds during the experimental period.

\begin{tabular}{|lccc|}
\hline Parameters & Treatment-I & Treatment-II & Treatment-III \\
\hline Average water depth $(\mathrm{m})$ & $0.92 \pm 0.01$ & $0.88 \pm 0.01$ & $0.95 \pm 0.02$ \\
\hline Water temperature $\left({ }^{\circ} \mathrm{C}\right)$ & $19.35 \pm 3.13$ & $19.35 \pm 3.13$ & $19.35 \pm 3.13$ \\
\hline Air temperature $\left({ }^{\circ} \mathrm{C}\right)$ & $21.14 \pm 3.23$ & $21.15 \pm 3.23$ & $28.69 \pm 0.81$ \\
\hline Transparency $(\mathrm{cm})$ & $29.43 \pm 1.37$ & $25.06 \pm 2.30$ & $20.68 \pm 2.82$ \\
\hline Dissolved oxygen $\left(\mathrm{mg} \mathrm{L}^{-1}\right)$ & $8.80 \pm 0.52$ & $8.43 \pm 0.51$ & $8.06 \pm 0.49$ \\
\hline Free $\mathrm{CO}_{2}$ & $2.97 \pm 0.40$ & $3.50 \pm 1.07$ & $4.27 \pm 0.36$ \\
\hline $\mathrm{pH}$ & $7.51 \pm 0.11$ & $7.58 \pm 0.08$ & $7.52 \pm 0.10$ \\
\hline $\mathrm{PO}_{4}-\mathrm{P}\left(\mathrm{mg} \mathrm{L}^{-1}\right)$ & $1.69 \pm 0.07$ & $1.81 \pm 0.02$ & $1.62 \pm 0.11$ \\
\hline $\mathrm{NO}_{3}-\mathrm{N}\left(\mathrm{mg} \mathrm{L}^{-1}\right)$ & $3.53 \pm 0.09$ & $3.52 \pm 0.18$ & $3.58 \pm 0.11$ \\
\hline Total Alkalinity $\left(\mathrm{mg} \mathrm{L}^{-1}\right)$ & $165.43 \pm 12.61$ & $168.37 \pm 5.34$ & $163.87 \pm 4.57$ \\
\hline
\end{tabular}

\section{Biological parameters}

The biological parameters such as phytoplankton density (cells $\mathrm{L}^{-1}$ ) and zooplankton density (cells $\mathrm{L}^{-1}$ ), generic status of phytoplankton and zooplankton, and growth and production of fish have been shown in Tables 3 to 4 .
Phytoplankton (cells L-1)

During the experimental period, 18 genera of phytoplankton belonging to 5 different groups of Bacillariophyceae, Chlorophyceae, Cyanophyceae, Dinophyceae, and Euglenophyceae were found in the experimental ponds (Table 3 ). The average density of phytoplankton of the ponds under 
treatment-I was 87.62 $\pm 4.32\left(\times 10^{3}\right)$ cells $\mathrm{L}^{-1}$ and Crustacea (Cladocera and Copepoda) and that of the ponds under treatment-II was Rotifera were found in the experimental ponds 88.06 $\pm 3.74\left(\times 10^{3}\right)$ cells L $\mathrm{L}^{-1}$ and that of the ponds (Table 3). The average density of zooplankton of under treatment-III was $91.43 \pm 4.13\left(\times 10^{3}\right)$ cells the ponds under treatment-I was $10.37 \pm 1.27$ $\mathrm{L}^{-1}$.

$\left(\times 10^{3}\right) 44$ cells $\mathrm{L}^{-1}$ and that of the ponds under treatment-II was $10.37 \pm 0.58\left(\times 10^{3}\right)$ cells $\mathrm{L}^{-1}$ and

Zooplankton (cells L-1) that of the ponds under treatment-III was

During the experimental period a total of 9 $10.50 \pm 1.10\left(\times 10^{3}\right)$ cells L-1. genera of zooplankton belonging to 3 group of

Table 3. Generic status of phytoplankton and zooplankton found in the culture pond.

\begin{tabular}{|c|c|c|c|c|}
\hline \multicolumn{5}{|c|}{ Phytoplankton } \\
\hline Chlorophyceae & Cyanophyceae & Bacillariophyceae & Dinophyceae & Euglenophyceae \\
\hline Actinastrum & Anabaena & Asterionella & Ceratium & Euglena \\
\hline Chlorella & Gomphospaeria & Cyclotella & & Phacus \\
\hline Pediastrum & Microsystis & Diatoma & & \\
\hline Scenedesmus & Oscillatoria & Fragilaria & & \\
\hline Ulothrix & & Navicula & & \\
\hline & & Tabellaria & & \\
\hline & & Zooplankton & & \\
\hline \multicolumn{4}{|c|}{ Crustacea } & Rotifera \\
\hline \multicolumn{2}{|c|}{ Cladocera } & \multicolumn{2}{|c|}{ Copepoda } & Brachionus \\
\hline \multicolumn{2}{|c|}{ Daphnia } & \multicolumn{2}{|c|}{ Cyclops } & Filinia \\
\hline \multicolumn{2}{|c|}{ Diaphanosoma } & & & Keratella \\
\hline \multicolumn{2}{|c|}{ Nauplius (Crustacean Larvae) } & & & Diaptomus \\
\hline \multicolumn{2}{|c|}{ Moina } & & & \\
\hline
\end{tabular}

\section{Survival rate, growth and production of fish}

Survival rate

The survival rates in treatment-I was $94.50 \%$ and in treatment-II was $94.00 \%$ and in treatment-III was $95.00 \%$. The survival rate in treatment-III is slightly higher than those in treatment-I and treatment-II (Table 5).

\section{Specific growth rate (\% per day)}

In treatment-I SGR value recorded was $0.962 \%$ per day and in treatment-II SGR value recorded was $0.980 \%$ per day and in treatment-III SGR value recorded was $0.850 \%$ per day. SGR value in treatment-II was higher than those in treatment-I and III (Table 5).

\section{Production of fish}

The calculated gross production of fish of the ponds under treatments I, II, and III were 5.328, 5.422 , and 4.216 ton ha- ${ }^{-1} \mathrm{yr}^{-1}$, respectively (Table 4). The net productions of fish of the ponds under treatments I, II, and III were 3.554, 3.648, and 2.919 ton ha-1 $\mathrm{yr}^{-1}$, respectively (Table 4). The gross and net productions of treatment-II were higher than those of other two treatments.

Table 4. Gross and net production of fish of the ponds under treatments I, II, and III.

\begin{tabular}{|c|ccccc|}
\hline \multirow{2}{*}{ Treatment } & \multicolumn{4}{|c}{ Kg decimal ${ }^{-1} \mathrm{yr}^{-1}$} & \multicolumn{2}{c|}{ Ton $\mathrm{ha}^{-1} \mathrm{yr}^{-1}$} & Production & $\begin{array}{c}\text { *Percent } \\
\text { increase of net } \\
\text { production }\end{array}$ \\
\cline { 2 - 6 } & Gross & Net & Gross & Net & $100.00 \%$ \\
\hline T-I & 21.318 & 14.220 & 5.328 & 3.554 & $102.64 \%$ \\
\hline T-II & 21.693 & 14.595 & 5.422 & 3.648 & $82.13 \%$ \\
\hline T-III & 18.777 & 11.679 & 4.216 & 2.919 & \\
\hline
\end{tabular}

*Percent increase of net productions of treatment-II and treatment-III, over treatment-I which has been taken for $100 \%$.

Table 5. Total survival rate, growth and production (gross and net) of fishes under treatments I, II, and III.

\begin{tabular}{|c|c|c|c|c|c|c|}
\hline \multirow[t]{2}{*}{ Treatments } & \multirow{2}{*}{$\begin{array}{l}\text { Total } \\
\text { survival } \\
\text { rate(\%) }\end{array}$} & \multirow{2}{*}{$\begin{array}{c}\text { Final total weight } \\
\text { (kg decimal-1 } 3.67 \\
\text { months }^{-1} \text { ) }\end{array}$} & \multirow{2}{*}{$\begin{array}{c}\text { Initial total } \\
\text { weight (kg } \\
\text { decimal-1) }^{-1}\end{array}$} & \multirow{2}{*}{$\begin{array}{c}\text { Specific } \\
\text { growth rate } \\
\text { (SGR \% per } \\
\text { day) }\end{array}$} & \multicolumn{2}{|c|}{ 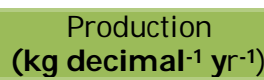 } \\
\hline & & & & & Gross & Net \\
\hline T-I & 94.50 & 7.106 & 2.366 & 0.962 & 21.318 & 14.220 \\
\hline T-II & 94.00 & 7.231 & 2.366 & 0.980 & 21.693 & 14.592 \\
\hline T-III & 95.00 & 6.259 & 2.366 & 0.850 & 18.777 & 11.679 \\
\hline
\end{tabular}




\section{Discussion}

The results of the study on various water quality parameters, the effects of organic fertilizers on growth and production of tilapia in monoculture system and cost-return relationship have been discussed below.

\section{Water quality parameters}

Suitable water quality parameters are prerequisite for sufficient production of fish food organisms on which fish production is dependent.

\section{Physical parameters}

The results of the different physical parameters during the experimental period were within the acceptable limits for fish culture and these have been discussed below.

Water depth (m)

Rahman (1992) quoted that pond should not be shallower than $1 \mathrm{~m}$ and deeper than $5 \mathrm{~m}$ and optimum depth should be $2 \mathrm{~m}$. The mean values of water depth under treatments-I, II and III were $0.921 \pm 0.01 \mathrm{~m}, 0.88 \pm 0.01 \mathrm{~m}$ and $0.90 \pm 0.01 \mathrm{~m}$, respectively.

\section{Transparency (cm)}

The mean values of water transparency of the ponds under treatment-I, treatment-II and treatment-III were $29.43 \pm 1.37 \mathrm{~cm}, 25.06 \pm 2.30$ $\mathrm{cm}$ and $20.68 \pm 2.82 \mathrm{~cm}$, respectively. Rahman (1992) stated that the transparency of productive water bodies should be $40 \mathrm{~cm}$ or less (turbidity resulting from plankton).

Water temperature $\left({ }^{\circ} \mathrm{C}\right)$

In the current experiment, the water temperature fluctuated from 15.82 to $24.49^{\circ} \mathrm{C}$. Ali (1998) stated that water temperature of ponds remain 20.20 to $36.50^{\circ} \mathrm{C}$ which was favorable to fish culture.

\section{Air temperature}

The range of air temperature was 31.57 to $11.54^{\circ}$ C. Kadir et al. (2007) described that the water temperature is always less than the surrounding air temperature and varied with 3 ${ }^{\circ} \mathrm{C}$.

\section{Chemical parameters}

During the experimental period, all the chemical parameters were found within the acceptable range for fish culture, which has been discussed below.

Dissolved oxygen ( $\left.\mathrm{mg} \mathrm{L}^{-1}\right)$

The mean values of dissolved oxygen content recorded in the present experiment under
treatment-I, treatment-II and treatment-III were $8.80 \pm 0.52,8.43 \pm 0.51$, and $8.06 \pm 0.49 \mathrm{mg} \mathrm{L}^{-1}$, respectively. Ellis et al. (1946) reported that the dissolved oxygen content at levels of $3 \mathrm{ppm}$ or less should be regarded as hazardous to lethal and that of $5 \mathrm{ppm}$ or more is suitable for fish production.

\section{Free carbon dioxide $\left(\mathrm{mg} \mathrm{L}^{-1}\right)$}

The mean values of free $\mathrm{CO} 2$ content recorded in the current experiment under treatment-I, treatment-II and treatment-III were $2.97 \pm 0.40$, $3.50 \pm 1.07$, and $4.27 \pm 0.36 \mathrm{mg} \mathrm{L}^{-1}$, respectively. According to Lagler (1992), free CO2 more than $20 \mathrm{mg} \mathrm{L}^{-1}$ may be harmful to fishes and even lower concentrations may be equally harmful when dissolved oxygen content is less than $3 \mathrm{mg}$ $\mathrm{L}^{-1}$.

$\mathrm{pH}$ (hydrogen ion concentration)

The mean values of $\mathrm{pH}$ recorded in the current experiment under treatment-I, treatment-II and treatment-III were $7.51 \pm 0.11,7.58 \pm 0.08$, and $7.52 \pm 0.10$, respectively. Swingle (1967) stated that $\mathrm{pH} 6.5$ to 9.0 is suitable for pond fish culture.

Total alkalinity (mg L-1)

The mean values of total alkalinity in the current experiment under treatment-I, treatment-II and treatment-III were $165.43 \pm 12.61,168.37 \pm 5.34$, and $163.87 \pm 4.57 \mathrm{mg} \mathrm{L}^{-1}$, respectively. Boyd (1990) stated that total alkalinity of productive ponds should be $20 \mathrm{ppm}$ or more and fish production increases with the increase of total alkalinity

Phosphate-phosphorus (PO4-P) (mg L-1)

The mean values of PO4-P in the current experiment under treatment-I, treatment-II and treatment-III were $1.69 \pm 0.07,1.81 \pm 0.02$, and $1.62 \pm 0.11 \mathrm{mg} \mathrm{L}^{-1}$, respectively. Wahab et al. (1995) found the concentration of phosphatephosphorus to vary from 0.09 to $5.20 \mathrm{mg} \mathrm{L}^{-1}$ in nine experimental ponds of Bangladesh Agricultural University Campus, Mymensingh.

Nitrate-nitrogen (NO3-N) (mg L-1)

The mean values of NO3-N in the present experiment under treatment-I, treatment-II and treatment-III were $3.53 \pm 0.09,3.52 \pm 0.18$, and $3.58 \pm 0.11 \mathrm{mg} \mathrm{L} \mathrm{L}^{-1}$, respectively. Das (2002) reported the range of nitrate-nitrogen values from 1.60 to $3.22 \mathrm{mg} \mathrm{L}^{-1}$, which is more or less close to the values obtained in the present experiment. 


\section{Biological parameters}

Phytoplankton

The average density of phytoplankton of the ponds under treatment-I was 87.62 $\pm 4.32\left(\times 10^{3}\right)$ cells $\mathrm{L}^{-1}$ and that of the ponds under treatment-II was 88.06 $\pm 3.74(\mathrm{x} \mathrm{103})$ cells $\mathrm{L}^{-1}$ and that of the ponds under treatment-III was $91.43 \pm 4.01\left(\times 10^{3}\right)$ cells $\mathrm{L}^{-1}$.

\section{Zooplankton}

During the present experiment the mean values of zooplankton in the experimental ponds under treatment-I, treatment-II and treatment-III were $10.37 \pm 1.27\left(\times 10^{3}\right), \quad 10.37 \pm 0.58\left(\times 10^{3}\right)$ and $10.50 \pm 1.10\left(\times 10^{3}\right)$ cells $\mathrm{L}^{-1}$, respectively. Mazid (2009), Chowdhury (2005), Kabir (2003) and Rashid (1999) observed more or less similar results in different experimental ponds.

\section{Survival rate, growth and production of fish}

Survival rate (\%)

The survival rates in treatment-I was $94.50 \%$, in treatment-II was $94.00 \%$ and in treatment-III was $95.00 \%$. Kohinoor (2000) reported the survival rates of $86.00 \%$ to $94.00 \%$ in the monoculture of Thai sarpunti.

Specific growth rate (SGR\% per day)

The specific growth rate in treatment-I, II and III were $0.962 \%, 0.980 \%$ and $0.850 \%$, respectively. Ridha (2006) reported the SGR value of fish was 1.10 and $0.87 \%$ per day, which is more or less similar to the present study.

Production of fish

In the present experiment, calculated gross and net productions of tilapia of the ponds under treatment-I ( $2 \mathrm{~kg}$ cow dung per 2 weeks per decimal) were 5.328 ton $\mathrm{ha}^{-1} \mathrm{yr}^{-1}$ and 3.554 ton $\mathrm{ha}^{-1} \mathrm{yr}^{-1}$ and those of the ponds under treatmentII ( $4 \mathrm{~kg}$ cow dung per 2 weeks per decimal) were 5.422 ton ha- $\mathrm{yr}^{-1}$ and 3.648 ton ha-1 $\mathrm{yr}^{-1}$ and those of the ponds under treatment-III ( $6 \mathrm{~kg}$ cow dung per 2 weeks per decimal) were 4.216 ton ha- $^{-1}$ $\mathrm{yr}^{1}$ and 2.919 ton $\mathrm{ha}^{-1} \mathrm{yr}^{-1}$, respectively. The highest production of fish was found from treatment-II (4 kg cow dung per 2 weeks per decimal) because of medium application of organic fertilizers. Diana et al. (1994) demonstrated that organic fertilizers result in higher primary production and consequently higher carps and catfish yields, apparently due to increased production of both autotrophic and heterotrophic organisms. In the present experiment, higher amounts of organic fertilizers result in lower production due to probably water quality deterioration slightly.
From the above discussion, it is apparent that treatment-I $(2 \mathrm{~kg}$ cow dung per 2 weeks per decimal) is the best in respect of cost-benefit analysis (ratio 1:0.81) among the three treatments. Therefore, it might be recommended that $2 \mathrm{~kg}$ cow dung per 2 weeks per decimal is the best for monoculture of tilapia.

\section{References}

Ali, M.H. 1998. The potential of periphyton-based monoculture of a major carp, Calibaush Labeo calbasu (Hamilton). M.S. Thesis, Department of Fisheries Management, Bangladesh Agricultural University, Mymensingh, Bangladesh. p.32.

Boyd, C.E. 1990. Water Quality in Ponds for Aquaculture, Birmingham Publishing Company, Birmingham, Alabama, United States of America. $477 \mathrm{p}$.

Chowdhury, M.M.R. 2005. Use of duckweed (Lemna minor) as supplementary feed in monoculture of Tilapia (Oreochormis niloticus). M.S. Thesis, Department of Fisheries Management, Bangladesh Agricultural University, Mymensingh, Bangladesh. p. 48.

Das, B.C. 2002. Studies on the effects of stocking density on growth, survival and yield of Amblypharyngodon mola and performance of Rohte cotio in combination with Barbodes gonionotus and with Cyprinus carpio in rice fields. M.S. Thesis, Department of Aquaculture, Bangladesh Agricultural University, Mymensingh, Bangladesh. p.12.

Diana, J.S., Lin, C.K. and Jaiyen, K. 1994. Supplemental feeding of tilapia in fertilized ponds. J. World Aqua. Soc. 25: 497-506.

DoF. 2011. Fisheries Statistical Yearbook of Bangladesh (July 2010 - June 2011), Department of Fisheries, Ministry of Fisheries and Livestock, Bangladesh. p. 11.

Ellis, M.M., Westfall, B.A. and Ellis, M.D. 1946. Determination of water quality, Fish and Wild life service, United States Department of Interior Resource, Report 9. 122p.

Gupta, M.V. and Noble, F. 2001. Integrated chicken-fish farming. pp. 49-53. In: M Halwart, J Gonsalves and M Prein (Editors), Integrated agriculture-aquaculture: A primer, FAO Fisheries Technical Paper 407, FAO, Rome.

Kabir, A.N.M.A. 2003. Use of duckweed (Lemna minor) as feed for fishes in polyculture. M.S. Thesis, Department of Fisheries Management, Bangladesh Agricultural University, Mymensingh, Bangladesh. p. 34.

Kadir, A., Wahab, M.A., Milstein, A., Hossain, M.A. and Seraji, M.T.I. 2007. Effects of silver carp and the small indigenous fish mola, Amblypharyngodon mola and punti, 
Puntius sophore on fish polyculture production. Aqua. 273: 520-531.

Knud-Hansen, C.F. 1998. Pond Fertilization: Ecological Approach and Practical Application. Pond Dynamics/Aquaculture Collaborative Research Support program. Oregon State University. pp. 15-27.

Kohinoor, A.H.M. 2000. Development of culture technology of three small indigenous fish mola (Amblypharyngodon mola), punti (Puntius sophore) and chela (Chela cachius) with notes on some aspects of their biology. $\mathrm{PhD}$ Thesis, Department of Fisheries Management, Bangladesh Agricultural University, Mymensingh, Bangladesh. p. 22.

Lagler, K.F. 1992. Freshwater Fisheries Biology, W.M.C. Brown Company Publisher, Dubuque, IOWA. 421 p.

Mazid, M.A. 2009. Impacts of fish population density on the growth and production of carp in polyculture system. M.S. Thesis, Department of Fisheries Management, Bangladesh Agricultural University, Mymensingh, Bangladesh. p. 65.

Rahman, A.K.A. 1992. Tilapia in Bangladesh. pp. 27-29. In: EA Balayut (Editor) Paper Contributed to the Workshop on Tilapia in Capture and Culture enhance Fisheries in Indo-Pacific Fishery Commission Countries.
Rahman, M.S. 1992. Water Quality Management in Aquaculture. BRAC Prokashana, Dhaka. 84p.

Rashid, M.M. 1999. Effects of periphyton on monoculture of Labeo gonius. M.S. Thesis, Department of Fisheries Management, Bangladesh Agricultural University, Mymensingh, Bangladesh. p. 45.

Ridha, T.M. 2006. Comparative study of growth performance of three strains of Nile tilapia, Oreochromis niloticus (L.) at two stocking densities. Aqua. 37: 172-179.

Saha, K.C.S., Gupta, J. and Bhattachaurya, A.N. 1980. Limiting factors controlling the production of Indian major carps fry in nursery ponds. Seminar on production of quality fish seed for fish culture. International Council of Agricultural Research. pp. 1-2.

Swingle, H.S. 1967. Standardizations of chemical analyses for waters and pond muds. FAO Fisheries Report. pp. 397-421.

Wahab, M.A., Ahmed, Z.F., Islam, M.A. and Rahmatullah, S.M. 1995. Effect of introduction of common carp, Cyprinus carpio (L), on the pond ecology and growth of fish in polyculture. Aqua. Res. 26: 619628. 